\title{
Congressional Fellowship Program Announces 2012-13 Fellows
}

$\mathrm{F}$ ounded in 1953, the APSA Congressional Fellowship Program is the nation's oldest and most prestigious congressional fellowship. The program remains devoted to its original objective of expanding knowledge and awareness of Congress. For nine months, select political scientists, journalists, doctors, federal executives, and international scholars gain "hands on" understanding of the legislative process by serving on congressional staffs. Through this opportunity, the association enhances public understanding of policymaking and improves the quality of scholarship, teaching, and reporting on American national politics. For more information, please visit http://www.apsanet.org/content_3031.cfm. Individuals selected for the program for 2012-13 are listed below.

\section{POLITICAL SCIENTIST}

Amir Shawn Fairdosi, PhD Candidate, University of Chicago

Joshua Carstens Huder, PhD Candidate, University of Florida

Anthony J. Madonna, PhD, University of Georgia

Melanie M. Marlowe, PhD Candidate, Miami University of Ohio

Tyson King-Meadows, PhD, University of Maryland - Baltimore County

Ian Ostrander, PhD Candidate, Washington University, St. Louis

Kevin H. Wozniak, PhD Candidate, American University

\section{JOURNALIST}

Scott Gutierrez, Transportation Reporter, Seattlepi.com

\section{AMERICAN AUSTRALIAN ASSOCIATION}

Rebekah Grindlay, Candidate, Masters in Public Policy, Princeton University

\section{ASIA FOUNDATION}

Maes Suwantra, Second Secretary, Ministry of Foreign Affairs of the Kingdom of Thailand

\section{ATLANTIC PHILANTHROPIES- HEALTH AND AGING POLICY FELLOWS}

\section{Residential}

Christine E. Bishop, PhD, Atran Professor of Labor Economics, Schneider Institute for Health Policy, The Heller School for Social Policy and Management, Brandeis University

Maureen Henry, Esq., Executive Director, Utah Commission on Aging, Director, Utah Aging and Disability Resource Connection
Joan D. Penrod, MSW, PhD, Associate Professor and Research Health Science Specialist, Mount Sinai School of Medicine, Department of Geriatrics and Palliative Medicine and James J. Peters VAMC Geriatric Research, Education and Clinical Center (GRECC)

Brooke Hollister, PhD, Assistant Professor, Medical Sociology, Aging Health and Social Policy, University of California, San Francisco

\section{Non-residential}

Emily Nicklett, PhD, Assistant Professor, University of Michigan School of Social Work

Kenneth Brummel-Smith, MD, Charlotte Edwards Maquire Professor and Chair, Department of Geriatrics, Florida State University college of Medicine

Susan C. Lynch, Esq., Health Care Trial Attorney, US Department of Justice, Lead Counsel, DOJ Nursing Home \& Elder Justice Initiative, Adjunct Professor of Law, George Washington University Law School, PhD candidate, Johns Hopkins Bloomberg School of Public Health, Department of Health Policy and Management

Arlene Bierman, MD, MS, Endowed OWHC Chair in Women's Health, Associate Professor, Health Policy, Management and Evaluation; Nursing and Medicine, Keenan Research Center in the LI Ka Shing Knowledge Institute, St. Michael's Hospital and the University of Toronto

Joan K. Davitt, PhD, MSW, Assistant Professor and Hartford Geriatric Social Work Faculty Scholar and Co-Director Penn Aging Concentration, University of Pennsylvania, School of Social Policy and Practice

Rajean P. Moone, PhD, Community Impact Manager, Greater Twin Cities United Way

\section{FEDERAL EXECUTIVES}

Erik Abjornson, Analytic Manager, Central Intelligence Agency

Nicole L. Fletcher, Budget Referent and Formulation Lead, Directorate of Science and Technology, Central Intelligence Agency

Jason E. Thomas, Deputy Chief, Office of Global Services Training Central Intelligence Agency

Christopher A. Landberg, Deputy Director, Force Reintegration Cell, International Security Assistance Force, Kabul, Afghanistan, US Department of State

\section{ROBERT WOOD JOHNSON FOUNDATION}

Barbara Damron, PhD, RN, FAAN, Associate Professor, University of New Mexico College of Nursing Director, Office of Community Partnerships and Cancer Health Disparities, University of New Mexico Cancer Center

Karen B. Domino, MD, MPH, Professor and Vice Chair for Clinical Research, Department of Anesthesiology and Pain Medicine, Adjunct Professor, Neurological Surgery, University of Washington School of Medicine

Bruce Edgren, PharmD, Associate Professor and Chair, Department of Pharmacy Practice and Administration, Saint Joseph College

Stephen Ferrara, MD, MC, USN, Commander and Chief of 
Interventional Radiology, Department of Radiology, US Navy

Andrew Gettinger, MD, Associate Dean for Clinical Informatics and Professor, Dartmouth Medical School, Chief Medical Information Officer, Dartmouth-Hitchcock Medical Center
Harry J. Heiman, MD, MPH, Assistant Professor, Department of Family Medicine, Director of Health Policy, Satcher Health Leadership Institute, Morehouse School of Medicine

Peter Sokolove, MD, Professor and Vice Chair for Academic Affairs, Department of Emergency Medicine,
University of California Davis Health System

Hassan A. Tetteh, MD, MPA, Department of Cardiothoracic Surger, National Naval Medical Cente, Commander, Medical Corps, US Navy 


\section{American Political Science Association}

\section{Call for Applications 2013-2014 Congressional Fellowship Program}

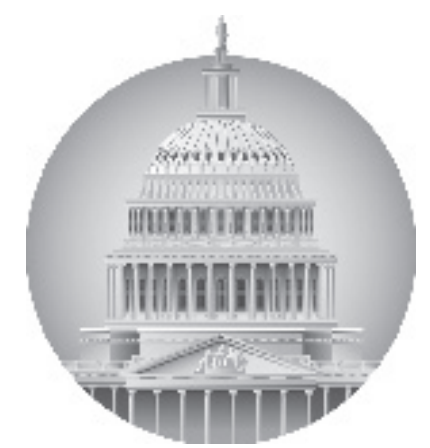

\section{CFP Advisory Committee}

Michael Barone, U.S. News \& World Report Doug Bereuter, Asia Foundation Richard Cohen, National Journal Charles E. Cook, Jr., Cook Political Report Joan Claybrook*, Public Citizen Robert Dole, Former Republican Leader, U.S. Senate

Ronald D. Elving, * National Public Radio Eugene Eidenberg*, Granite Ventures, LLC Vic Fazio, Clark \& Weinstock

Thomas Foley, Former Speaker of the U.S. House of Representatives

Michael Franc, Heritage Foundation William Frenzel, Brookings Institution David Gergen, Harvard University Robert G. Gilpin, Jr.*, Princeton University Lee H. Hamilton, Woodrow Wilson Center Albert Hunt, Bloomberg News Gary Hymel, Hill \& Knowlton Charles O. Jones, Brookings Institution Gerald Kovach, NeuStar Richard Lugar, U.S. Senate

Robert Merry, former CEO, Congressional Quarterly

Norman Ornstein*, American Enterprise Institute

David Price, U.S. House of Representatives Cokie Roberts, ABC News

Catherine E. Rudder*, George Mason University

Barbara Sinclair*, University of California, Los Angeles

* Former APSA Congressional Fellow
WHO: Early and mid-career political scientists with a scholarly interest in Congress and the policymaking process.

WHAT: A comprehensive four-week orientation period; full-time assignments as legislative aides in the House of Representatives and the Senate; the biweekly Wilson Seminar series with leading congressional, governmental and academic figures; a visit to the District or State of a Member of Congress; and two legislative comparison programs in Annapolis, Maryland, and Ottawa, Canada.

WHY: To learn more about the legislative process through direct participation.

QUALIFICATIONS: Applications are welcome from political scientists who have completed a Ph.D. in the last 15 years or will have received their degree before the program begins.

THE FELLOWSHIP YEAR: Orientation begins November 2013. Office assignments run from December 2013 through August 15, 2014.

STIPEND: $\$ 38,000$, plus a travel allowance.

SELECTION: Preference is given to those who have not had extensive Washington experience.

APPLICATION PROCEDURE: Submit seven hole-punched copies each of:

- a detailed resume;

- a personal statement (around 500 words) explaining how the Congressional Fellowship Program relates to your professional goals;

- the names of three professional references who have agreed to write letters of recommendation; applicants are responsible for seeing that letters are received by December 15, 2012;

- a sample of your best writing (one published or unpublished manuscript).

Please submit all materials collated in the order listed above, on three-hole punched paper. Materials may be stapled or clipped, but applications in report covers will not be accepted.

APPLICATION DEADLINE: Must be postmarked by December 1, 2012.

www.apsanet.org/cfp 